bite" results without actual freezing of the tissues. This leads me to point out that freezing of the tissues is not always productive of frost-bite. We commonly freeze the surface tissues with ethyl chloride in producing local anæsthesia, and only meet with frost-bite in those cases where exploratory punctures only are effected through the frozen area; never when the area is freely incised, as in opening an abscess.

I would accept Captain Lake's statement that short of actual tissue destruction much of the damage observed is due to exudation, and would explain the absence of frost-bite in these cases by the free escape of the exudate permitted by the incisions. Thus early incision of frost-bitten areas might minimise the tissue destruction, and cupping or simple deep scarification may prove valuable in the treatment of some forms of "trench foot."

$$
\text { I am, Sị, yours faithfully, }
$$

$$
\text { H. LEIGHTON KaSTEVEN. }
$$

Gladstone, Queensland, Jan. 30th, 1918.

\section{ARMY NEPHRITIS.}

\section{To the Editor of THE LANCET.}

SiR,-I read in Captain C. F. Coombs's article on Army Nephritis in THE LANCET of April 6th that morphia gr. $\frac{1}{4}$ was given hypodermically for uræmic convulsions, and " no bad effects followed in any case" (p. 498, line 73).

I have not my case-book with me, but $I$ well remember causing morphia gr. $\frac{1}{4}$ to be administered by the skin to a girl, aged 9 years, who had a convulsion during postscarlatinal nephritis. In her case the fit was not repeated, and all albumin disappeared from her urine within five days. Her younger brother had the same disease but no convulsion, and was not treated with morphia. In his case the albumin persisted in the urine for several weeks, in spite of all ordinary treatment. I gave this apparently dangerous amount of morphia because of the undoubted success which had followed the hypodermic injections of morphia gr. $\frac{3}{4}$ to gr. i. in many cases of puerperal eclampsia. In all these puerperal cases the albumin quickly disappeared from the urine.

It would be interesting to know whether it did so also in those cases of Captain Coombs in which morphia was used, and more rapidly than in the other patients.

I am, Sir, yours faithfully,

Reginald HaRTLEY, M.D. Durh., F.R.C.S. Edin.

Tunbridge Wells, April 6th, 1918.

\section{THE HOME OF RECOVERY, GOLDERS GREEN.}

To the Editor of THE LANOET.

SIR,-I read your admirable annotation on " The Home of Recovery, Golders Green," with great appreciation. Treatment of neurasthenics to be really efficacious demands certain special personal qualities in the medical men in charge as well as special training for the work. When so many members of our profession are now urgently required for more active service it may be well to ask whether sufficient use is made of the older members, who are able and willing to do their part in promoting the recovery of injured soldiers. Surely in times like these an age limit should not be rigorously enforced. We are not all old at 65-e.g., General Foch.

April 6th, 1918.

$$
\text { I am, Sir, yours faithfully, }
$$

PARLIAMENTARY REPRESENTATION OF UNIVERSIrIES.-Arrangements are now complete for the compilation of the Register of Parliamentary Electors of the University of Durham. All graduates, other than those bolding honorary degrees, are qualified to be registered, and full particulars will be sent on application to the registrar, University Offices, Durham, but a stamped addressed envelope of foolscap size must be enclosed. A Bachelor's degree in any faculty gives the right to registration, but Licentiates in Theology only are not qualified to be registered.

\section{(Bbituaty.}

\section{ALFRED HENRY CARTER, M.Sc. BIRM., M.D. LOND.,} F.R.C.P. LOND.

Dr. Alfred Henry Carter, who died at his residence at Abingdon on April 4th, aged 69, was for many years a wellknown consulting physician residing in Birmingham, but being called into counsel over all the Midland district. For 40 years his high reputation among all classes of the community was deserved by the important character of his work.

Carter was the son of a Wiltshire medical man, was educated at Epsom, and studied for his profession at University College, London. He qualified by taking the M.R.C.S. Eng. and the L.S.A. in 1870, graduating in medicine with honours a year later at the University of London. Like so many young and energetic men of his day, he served in a field hospital throughout the Franco-German War, returning to take up resident posts at University College Hospital. In 1872 he proceeded to the M.D. Lond., and after brief service in the General Hospital at Wolverhampton was appointed pathologist to the General Hospital, Birmingham. He shortly obtained honorary positions on the staffs of the Children's Hospital and Queen's Hospital, Birmingham, and his private practice began to grow rapidly. In 1891 he became a Fellow of the Royal College of Physicians of London. As academic and clinical teacher both at the Queen's Hospital and at Mason College, where he was professor of physiology and therapeutics, he became well known, and when the educational work of the hospital was transferred to the College his chances increased and he was appointed examiner in the University of Aberdeen and later in that of London, while he delivered the Ingleby lecture at Mason College. In 1900 came about the constitution of the University of Birmingham, in which Carter was deeply and actively concerned. When Mason College, of which he was for some time honorary secretary, became practically erected into the University he was appointed professor of medicine, and was exceedingly successful in his new educational and administrative work from the beginning, for though a quiet and in some senses a retiring man he was a forceful character and devoted to his ideals. The honorary degree of Master of Science in the University was awarded to him in 1901 in special recognition of his services.

Although Carter wrote a good many short clinical papers, and was responsible for the usual number of public addresses, he was not a prolific author, but with one book alone he became one of the best-known British medical authors. The first edition of Carter's famous "Elements of Practical Medicine" appeared in 1881, at a time when the rapid and exact progress of medical knowledge made impossible any attempt to get between the covers of one book of convenient size a comprehensive picture of our science. There were at the time excellent manuals, and one or two systems and dictionaries of varying value in their different departments; such manuals and systems were bound to be replaced by larger and more modern substitutes, and the need for an authoritative epitome was felt by the students, if not by their teachers. The teachers held that such epitomes were best formed by their own lectures and their pupils' notebooks, and if all academic and clinical lecturers had been, or could be, competent for their work, and if all medical students had been, or could be, industrious and methodical, no doubt the teachers' view was right. But, as a matter of fact, the warning against Carter's "Elements of Practical Medicine," uttered in many lecture theatres, was completely disregarded; the work had from the beginning a large public, and thoroughly deserved its success, for it contained the essentials of medicine stated in clear and explicit language without overburdening the reader with side issues and doubtful points. The facts were presented in a dogmatic way, this plan leaving no space for the proving of statements. In the course of five years four editions appeared without much modification and served numerous medical students in different ways-as an index to larger works, as a ready-made note-book, as a scheme on which to plan systematic study, and as a guide to rapid revision before examinations. Fifteen years later the book, still preserving much of its original shape and scope, was enjoying the same popularity 